\title{
MEMORIES OF FATHER AND MOTHER ACCEPTANCE/ REJECTION AND ITS RELATIONSHIP WITH GENDER
}

\author{
Piedade Vaz-Rebelo \\ Faculty of Psychology and Educational Sciences \\ University of Coimbra \\ Portugal \\ pvaz@fpce.uc.pt \\ Graciete Franco-Borges \\ Faculty of Psychology and Educational Sciences \\ University of Coimbra \\ francoborges@fpce.uc.pt \\ Maria da Luz Vale-Dias \\ Faculty of Psychology and Educational Sciences \\ University of Coimbra \\ Portugal \\ valedias@fpce.uc.pt
}

Fecha de Recepción: 8 Mayo 2019

Fecha de Admisión: 25 Septiembre 2019

\begin{abstract}
The aim of this study is to characterize young adults' memories of mother and father acceptance and rejection and to analyse different patterns of mother and father perception of acceptance and rejection for girls and boys. The research was developed in a sample of 180 Portuguese university students and the instruments used were the Adult-PARQ Father (short form) (Rohner, 2004), the Adult-PARQ Mother (short form) (Rohner, 2004) and a sociodemographic questionnaire. The preliminary results evidenced that Adult-PARQ Father and Adult-PARQ Mother (short form) (Rohner, 2004) have very good psychometric characteristics and that there is a statistically significant difference between boys and girls perceptions of mother and father acceptation and hostility-aggression.

Keywords: parental acceptance and rejection; memories; gender

\section{INTRODUCTION}

The role of parental rearing attitudes and behaviors in child development has been extensively evidenced in research on the topic (Vaz- Rebelo \& Franco-Borges, 2009). For instance, the positive impact of the dimension of parental acceptance and the negative one of parental rejection attitudes on development has been analysed in the scope of the Parental acceptance-rejection theory (PART
\end{abstract}


Theory, Rohner, 2008; Rohner, \& Khaleque, 2005), that aims to extended the evidenced already gathered in childhood and adolescence to other stages of lifespan. and considering the differential impact of some variables as gender. The aim of this study is to characterize young adults' memories of mother and father acceptance and rejection and to analyze different patterns of mother and father perception of acceptance and rejection for girls and boys.

\section{METHODOLOGY}

The research was developed in a sample of 180 Portuguese Higher Education students from Engineer, Psychology, Nursing and Social Education courses. Girls are slightly more represented as there are 90 girls and 78 boys.

The instruments used were the Adult-PARQ Father (short form) (Rohner, 2004), the Adult-PARQ Mother (short form) (Rohner, 2004) and a sociodemographic questionnaire. Both PARQ questionnaires include 24 statements about parental attitudes and behavior that happened when participants were children addressing Mother Acceptance, Mother Hostility, Mother Indifference and Mother Rejection, for Mother PARQ questionnaire, and Father Acceptance, Father Hostility, Father Indifference and Father Rejection, for Father ARQquestionnaire. Participants shall choose between four possibilities: Only Mother, Only Father, Mother and Father, Neither Mother nor Father.

Internal consistency of the questionnaires was measured through Alfa de Cronbach and values obtained were very good and are presented in Table 1.

Table 1. Alfa de Cronbach of the $P A R Q$ - mother and $P A R Q$ - father form

\begin{tabular}{|c|c|c|c|c|}
\hline de & $\begin{array}{l}\text { Acceptan } \\
\text { ce }\end{array}$ & $\begin{array}{l}\text { Hostility_Agr } \\
\text { ession }\end{array}$ & $\begin{array}{l}\text { Indifference_Negli } \\
\text { gence }\end{array}$ & Rejection \\
\hline $\begin{array}{l}\text { Cronbac } \\
\text { h }\end{array}$ & & & & \\
\hline $\begin{array}{l}\text { Mothe } \\
\mathrm{r}\end{array}$ & .904 & .843 & .776 & .746 \\
\hline Father & .904 & .790 & .805 & .826 \\
\hline
\end{tabular}

\section{RESULTS}

Memories of Mother and Father Acceptance, Rejection, Indifference and Negligence

Mean value of Memories of Father and Mother Acceptance, Rejection, Hostility and Indifference are presented in Figure 1. 
Figure 1. Frequency of memories of Mother and Father PARQ dimensions

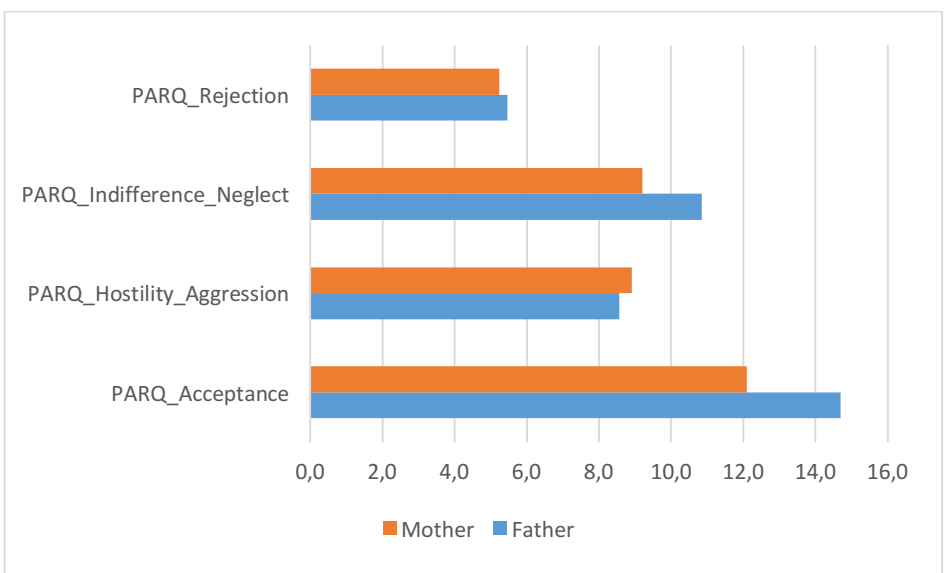

Participants referred more Memories of Father Acceptance than Memories of Mother Acceptance and this difference is statistically significant ( $t=-6.84, \mathrm{df}=157, \mathrm{p}>.000)$. Participants also referred more memories involving Father Indifference Neglect than memories involving Mother Indifference/Neglect and this difference is also statistically significant $(t=-6.44, d f=165, p>.000)$.

\section{Memories of Mother and Father Acceptance, Rejection, Indifference and Negligence for girls and boys}

Memories of Mother and Father PARQ dimensions for girls and boys are presented in Figure 2, evidencing the important of considering gender to a deep understanding of these memories. Boys memories have a higher level of Father Acceptance than girls' memories and this difference is statistically significant $(t=2.29, \mathrm{df}=165, \mathrm{p}=.023)$. A similar result was obtained on memoires of Mother Acceptance $(t=2.97, d f=166, p=.005)$ and memories of Father Hostility/Aggression $(t=1.99, d f=169$, $\mathrm{p}=.048)$.

Figure 2. Memories of Mother and Father PARQ dimensions

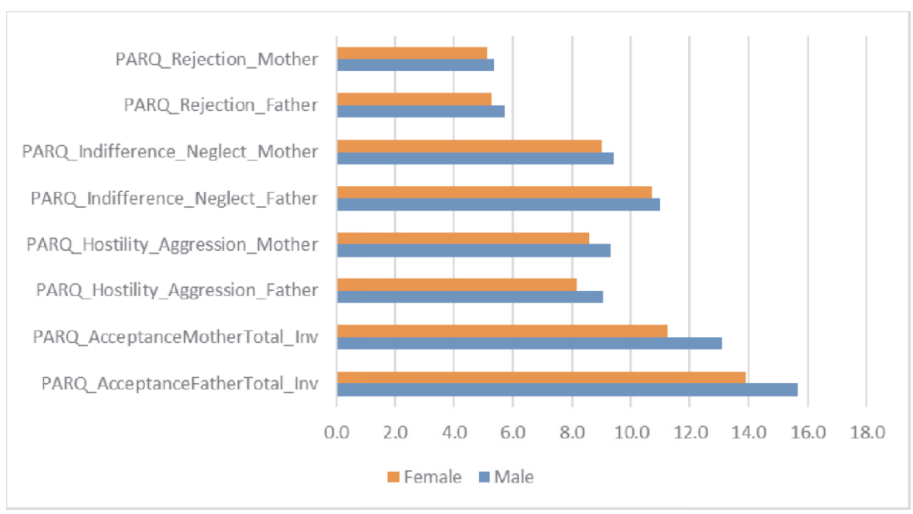




\section{CONCLUSIONS}

Results evidence the long-life impact of parental acceptance and rejection attitudes and behaviors and the importance to consider its differently on boys and girls. The prominence of memories involving father can be considered a support to the model that has been developing by Rohner, and Khaleque (2008) about the topic.

\section{BIBLIOGRAPHIC REFERENCES}

Rhoner, R. P. (2004). The parental "acceptance-rejection syndrome": Universal correlates of perceived rejection. American Psychologist, 59, 830-840.

Rhoner, R. P. (2008). Introduction: Parental Acceptance-Rejection Theory Studies of Intimate Adult Relationships. Cross-Cultural Research, 42(1), 5-12.

Rhoner, R. P., Khaleque, A. \& Cournoyer, D. E. (2005). Parental acceptance-rejection theory, methods, evidence, and implications. In R. P. Rhoner \& A. Khaleque (Eds.), Handbook for the study of parental acceptance and rejection (4th Edition, 1-35). Storrs, CT: Rohner Research Publications

Vaz-Rebelo, P. \& Franco-Borges, G. (2011). Parental Rearing Attitudes and Academic Failure: Analyzing Mediator Effects. In E. E. Kourkoutas \& F. Erkman (Eds.) Interpersonal Acceptance and Rejection: Social, Emotional, and Educational Contexts. Brownwalker Press. 